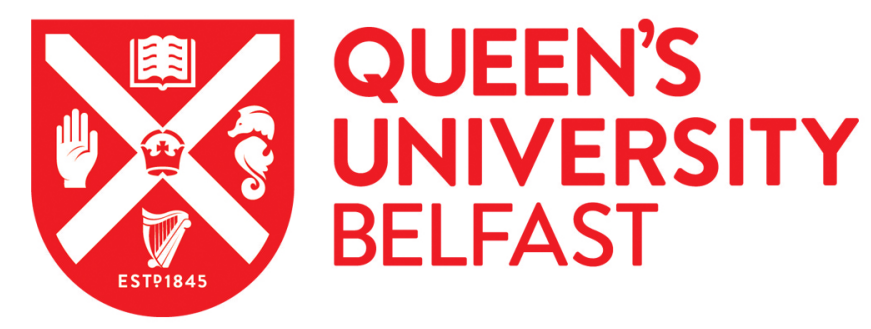

\title{
How States Order the World: A Typology of "Core" and "Peripheral" Foreign Policy
}

Pijovic, N. (2019). How States Order the World: A Typology of "Core" and "Peripheral" Foreign Policy. Foreign Policy Analysis. https://doi.org/10.1093/fpa/orz022

\author{
Published in: \\ Foreign Policy Analysis
}

\section{Document Version:}

Peer reviewed version

Queen's University Belfast - Research Portal:

Link to publication record in Queen's University Belfast Research Portal

\author{
Publisher rights \\ (C) The Author(s) (2019). Published by Oxford University Press on behalf of the International Studies Association. \\ This article is published and distributed under the terms of the Oxford University Press, Standard Journals Publication Model \\ (https://academic.oup.com/journals/pages/open_access/funder_policies/chorus/standard_publication_model)
}

\section{General rights}

Copyright for the publications made accessible via the Queen's University Belfast Research Portal is retained by the author(s) and / or other copyright owners and it is a condition of accessing these publications that users recognise and abide by the legal requirements associated with these rights.

Take down policy

The Research Portal is Queen's institutional repository that provides access to Queen's research output. Every effort has been made to ensure that content in the Research Portal does not infringe any person's rights, or applicable UK laws. If you discover content in the Research Portal that you believe breaches copyright or violates any law, please contact openaccess@qub.ac.uk. 


\section{How States Order The World}

\section{A typology of 'core' and 'peripheral' foreign policy'}

Every state's foreign policy deals with a multitude of simultaneously happening events and issues, all of which may require the government's attention, but not all of which will receive the same level of that attention. All states have limited resources, and foreign policy priorities must be made in order to pursue certain ideological, strategic, and economic interests which will hopefully help preserve or increase a state's general wellbeing. However, notwithstanding the large amount of literature on International Relations (IR) and Foreign Policy Analysis (FPA), theorizing how this hierarchy of interests affects foreign policy-making remains relatively underdeveloped.

Within IR literature, foreign policy is usually presented as the empirical product of relations between states (and non-state actors), generally devoid of theoretical underpinnings. ${ }^{2}$ Dominant IR theories such as the various strains of Realism highlight a state's overall priorities and goals (survival and power), but these are often too broadly conceived to guide us in understanding how such priorities are operationalized in foreign

\footnotetext{
${ }^{1}$ Author's note: I thank Prof Michael Wesley, Prof Valerie Hudson, Prof Kim Nossal, and Dr Tim Legrand on their comments on earlier versions of this paper, and the anonymous reviewers and journal editors at FPA for their feedback.

${ }^{2}$ For Waltz (1996: 54-55) theories of international politics have little to do with explaining foreign policies, which 'are governmental procedures'.
} 
policy, and how they influence everyday foreign policy-making (Wohlforth 2012: 43; Waltz 1996: 54). ${ }^{3}$

On the other hand, FPA literature, generally shunning IR's 'grand theorizing' about the behaviour of states, focuses instead on an attention to empirical detail, and the interdisciplinary and multicausal explanations of the nature of the processes of foreign policy decision-making and how these influence the final policy outputs (Hudson 2007). However, while FPA literature has made many advances in explaining foreign policy behaviour, given its heavy emphasis on the empirical study of numerous variables involved in foreign policy decision-making, it is often still unable to synthesize 'middlerange' theorizing on state foreign policy priorities and how those influence foreign policymaking.

While there have been attempts at explaining how foreign policy priorities influence foreign policy-making, these have largely been idiosyncratic, descriptive and lacking in theoretical synthesizing. A good example is the 'concentric circles' approach to understanding foreign policy priorities. Here, a state’s foreign policy interests are defined by geography, with the centre being the country in question, and the importance placed on foreign policy regions and issues diminishing as the concentric circles move farther away from the centre (Landsberg 2014). Although this approach is useful as a

\footnotetext{
${ }^{3}$ Rose (1998) does outline four substantive theories of foreign policy within Realism; innenpolitik, defensive realism, neoclassical realism, and offensive realism.
} 
general tool for understanding more and less important areas of a state’s foreign policy, it does not explain the different foreign policy-making dynamics vis a vis areas situated in different concentric circles, nor does it explain why foreign policy priorities change.

In order to improve our ability to explain foreign policy priorities and how they influence the nature of policy-making, I establish an ideal typology of 'core' and 'peripheral' foreign policy which categorizes more and less important foreign policy spaces and issues. 'Core' and 'peripheral' foreign policy sit at two opposite extremes of a state's foreign policy spectrum, and their determinants, processes, and goals can be markedly different. Avoiding dense empirical detail, and with a view to general theorizing, my aim is to further contribute to FPA's 'middle-range' theory by synthesizing ideas on 'structure and agency' in foreign policy to offer theoretically generalizable observations about these two distinct types of foreign policy (Carlsnaes 1992). ${ }^{4}$ My contribution is thus firmly in the European 'analysis of foreign policy' tradition, seeking to be 'more theoretically inclusive than FPA has been to date, embracing not only actor-specific theories, but also grand theory’ (Hudson 2012: 32), and heeding the call for theory development and integration in FPA (Hudson 2005: 20-21).

While much of the literature on foreign policy rarely highlights this explicitly, all foreign policy is determined by a combination of structural and agential factors. Structural

\footnotetext{
${ }^{4}$ For examples of FPA’s ‘middle range’ theorizing see Putnam's 'two level games' (1988), Mintz and Geva’s ‘polyheuristic theory’ (1997), and Alons’ ‘predicting foreign policy’ (2007).
} 
factors emphasize the context within which political events, outcomes, and effects occur and are beyond the immediate control of the actors directly involved, while agential factors emphasize the conduct of those actors, implying that their behaviour and choices are responsible for the effects and outcomes political scientists are interested in explaining (Hay 2002: 95-96). Factors such as the makeup of the international political economy and trading patterns, global ideological and power constellations, geography, defence capability, domestic politics, media and public opinion, individual decision-makers, and the decision-making process (to name a few), all play a role in determining 'core' and 'peripheral' foreign policy. Hence, the salience of structural or agential determinants of foreign policy will vary depending on the issue at stake, and where it sits on the spectrum between the two ideal types. This will also influence the differing dynamics of decisionmaking and different foreign policy goals.

I firstly outline the ideal typology of 'core' and 'peripheral' foreign policy, focusing particularly on their determinants, processes, and goals. Here, I explicitly examine how structure and agency influence the nature of foreign policy-making, by focusing on the qualitative differences between the two types. ${ }^{5}$ I then briefly examine

\footnotetext{
${ }^{5}$ An emphasis on quantitative indicators could make it rather easy to determine a state's 'core' and 'peripheral' foreign policy (by counting where most resources are invested), but such an examination would be more descriptive than analytical. A robust typology is better served by outlining the less observable, and almost certainly more contentious and debatable properties which make the two types of foreign policy qualitatively different.
} 
how foreign policy types change, before concluding with remarks on the value of an ideal typology of foreign policy for FPA’s 'middle-range' theorizing.

\section{'Core' and 'peripheral' foreign policy}

\section{'Core’ foreign policy}

'Core' foreign policy is where a government's top priorities lie. It is aimed at issues and regions considered of significant and primal ideological, strategic, and economic importance for a state’s immediate well-being. 6 'Immediate' well-being implies a value in whose pursuit decision-makers are willing to invest significant state resources and whose perceived benefits justify such investments. Such values need not be rationally determined, and include concerns over state survival, sovereignty, ideological alignment, regional or even global security and prosperity, and a host of other issues. 'Core' foreign policy is implicitly and/or explicitly defined by decision-makers (agents) who act on behalf of the state, but it is also underpinned by structural factors beyond their immediate control. Hence, while agents define what 'core' foreign policy entails, their definition is underpinned by the structural conditions informing and influencing their world-view.

\footnotetext{
6 'Strategic' implies a broad understanding of security and geo-political issues, and an appreciation of the role diplomacy plays in them as well, rather than a narrow focus on conventional security/military concerns.
} 
Ideological, strategic, and economic interests in foreign policy are all interwoven in a state's foreign policy priorities, and do not lend themselves to easy separation, but for analytical purposes some basic distinctions must be attempted. A state’s ‘core’ foreign policy with regards to ideological interests would be concerned with maintaining and/or improving links with other states it considers itself sharing certain fundamental cultural, historical, normative, and socio-political affinities with. This would include the style of political or economic governance; religious, linguistic, racial, and historical links; and a shared affinity for the ideas and values that are believed to constitute the fundamental principles of statehood and a proclaimed 'way of life'. 'Core' foreign policy ideological issues would also include the pursuit of certain ideational, moral, and ethical goals seeking to shape the international environment.

Such ideological interests are almost daily defined by decision-makers (through speeches and official documents), but hold longevity because they are also underpinned by structural factors that are beyond the decision-makers' immediate control (for example, the 'special relationship' between the United States and United Kingdom is often invoked by both sides as a bedrock of their relationship, pre-dating the decisionsmakers invoking it, who, nevertheless, still play a role in perpetuating that relationship for future generations). All of these ideological affinities may change over time, but the rapidity of these changes would primarily be influenced by the state's political system. Authoritarian or dictatorial regimes might move more rapidly to shift ideological 
affinities, while pluralist multiparty regimes can be slower to undertake such shifts. Changing demographics would also play a role in this process, although potentially having more salience for pluralist multiparty than authoritarian or one-party political systems.

Strategic interests in ‘core’ foreign policy can easily be understood through Karl Deutsch et al.’s ‘security communities’ and Barry Buzan’s ‘security complexes’. Deutsch et al. (1968: 5, 36) defined 'security communities' as communities where there was 'real assurance that the members of that community will not fight each other physically', but 'settle their disputes in some other way', and that the sense of community related to mutual sympathy and loyalties, a 'we-feeling', trust, partial identification in terms of selfimages and interests, and mutually successful prediction of behaviour. 'Security communities' often arise where neighbours seek to cooperate, and neighbourly cooperation and regional integration are still the main foundations for 'security communities'.

In defining ‘regional security’ Barry Buzan (1991: 190) highlighted ‘the pattern of amity and enmity among states' which gives rise to a 'security complex': 'a group of states whose primary security concerns link together sufficiently closely that their national securities cannot realistically be considered apart from one another' (e.g. Canada and the United States). Security complexes are principally defined by a 'high level of threat/fear which is felt mutually among two or more major states', while 'a high level of 
trust and friendship can also serve as a binding force' (original emphasis) (Buzan 1991: 193-194). Membership in security complexes in many ways determines a state's interpretation of what constitute threats to national security and how to go about mitigating them. Hence, strategic interests within 'core' foreign policy are usually dominated by the state’s membership in certain security communities/complexes.

‘Core' foreign policy economic interests are concerned with maintaining and/or improving relations with key trading partners, and access to raw materials and energy security. They are also concerned with promoting foreign and trade policies which benefit particular industries and companies of strategic importance to the country's economic well-being (historically by imperial expansion, or in contemporary terms by pursuing market access and trade agreements). Here it is particularly obvious that while decisionmakers (agents) may define what economic matters fall within their state’s ‘core’ foreign policy, structural issues beyond their control, such as national economic aggregates and international trading patterns, underpin and inform those perceptions of 'core' economic interests.

Finally, 'core' foreign policy can empirically be identified by the high prominence ascribed to it in decision-makers' (agents') foreign policy pronouncements and rhetoric (ministerial or presidential speeches, parliamentary statements, etc.) and dominant institutional discourses (departmental White Papers, National Security Statements, strategic documents, etc.). However, 'core' foreign policy is not only 'core' because 
agents say so: it is also identified by structural underpinnings which inform those agents' perceptions, but are beyond their immediate control. Thus, a useful empirical indicator of 'core' foreign policy, highlighting the importance of structural factors beyond agents' immediate control is 'issue salience'. 'Issue salience' indicates 'the relative importance or significance that an actor ascribes to a given issue on the political agenda', highlighting 'the issue's overall prominence in the minds of decision makers' (Oppermann and Spencer 2013: 41). While usually associated with media and public opinion influence on foreign policy-making, ‘issue salience’ can also help identify many other structural factors - international norms, cultural and ideological preferences, etc. - which are beyond the immediate control of agents, but depending on their importance to those agents will indicate a matter of 'core' or 'peripheral' foreign policy. ${ }^{7}$

\section{'Peripheral' foreign policy}

'Peripheral' foreign policy is low on a government's foreign policy agenda, and aimed at issues and regions considered of marginal ideological, strategic, and economic importance for a state's immediate well-being. Again, while defined by decision-makers (agents), it is underpinned by structural factors, representing a policy space with low

\footnotetext{
${ }^{7}$ The key to distinguishing between 'core' and 'peripheral' foreign policy based on issue salience is 'salience threshold' - when an issue becomes important enough for decision makers' to elevate it to a 'core' foreign policy status. However, 'salience threshold' is a relational concept, difficult to quantify, and in the empirical analysis, 'the distinction between high- and low-salience issues will always have to come from a qualitative and comparative summary judgment of different measures of issue salience' (Oppermann 2014: 27).
} 
‘issue salience’: in whose pursuit decision-makers are unwilling to invest significant state resources; where ideological values do not generally necessitate greater foreign policy engagement; where strategic interests cannot be significantly threatened or advanced; and where economic interdependence (or the benefit of economic engagement) is weak or non-existent (e.g. Canada's engagement with Togo or Tuvalu). This does not suggest a state would have absolutely no interest in engaging with such issues and regions, but that the salience of such interests is low, and they are perceived by decision-makers as holding limited priority and importance, relative to the limited amount of resources a government can pour into foreign policy.

\section{Structure, Agency, and the process of 'Core' and 'Peripheral' foreign policy}

Policy-making processes and foreign policy decision-making can determine the nature and goals of foreign policy, and here the discussion of structure and agency offers useful insights. All explanations of foreign policy decisions and behaviour highlight and analyse structural and agential factors. The issue of structure and agency is the 'central problem in social and political theory', and lies 'at the heart of the philosophy of the social and political sciences’ (Carlsnaes 1992: 245; Hay 1995: 192). While dominant IR theories, such as Realism, emphasize structural factors determining foreign policy (Waltz 1979), FPA emphasizes agential factors (Hudson 2005: 2-3). However, one of the advancements of contemporary political science has been the realization that both structure and agency can and do affect each-other in a dynamic relationship (Carlsnaes 
1992: 245-246; 2012: 124; Hay 2002: 115-135; Wight 2006: 101, 176, 210). As a leading theorist of structure and agency in FPA, Walter Carlsnaes (2012: 125), has argued, there is a need for the 'recognition and acceptance of the empirical fact that all foreign policy actions... are linked together in the form of intentions, cognitive-psychological factors, and the various structural phenomena characterizing societies and their environments' (emphasis original).

The main foreign policy decision-making agents (e.g. presidents, prime ministers, foreign ministers, top-level bureaucrats) upon entering office and/or being able to commit state resources to the enactment of foreign policy, are always presented with an unevenly contoured and biased structural terrain which both promotes and obstructs certain foreign policy choices (Friedman and Starr 1997: 6). Such agents find themselves in certain circumstances and internalize perceptions of the structures they have encountered, consciously adopting policy-making strategies which are informed by their assessment of those structures. On the whole, whatever foreign policy choices these agents make will serve to reinforce, or challenge the structural conditions they face (Hay 2002: 129-131). However, structural factors underpin, but do not by themselves mandate continuity or change in foreign policy; they do not directly determine outcome, merely helping define the potential range of options and strategies (Hay 2002: 200). It is agents who affect continuity and change in foreign policy because it is up to those in charge of developing 
and executing foreign policy to actively pursue certain decisions based on their perceptions, which are to an extent informed by structural factors.

The process of making 'core’ foreign policy is generally significantly structurally bounded because of the rigidness and high-salience of structures, and crowdedness of factors, influencing its content. The parameters of the relationship with a certain state can be influenced by an entrenched military alliance or significant economic (inter)dependency, media pressure, high 'issue salience' and public opinion, and the intense and politically influential advocacy of interest groups; all of which will significantly constrain or enable a decision-maker's (agent's) ability to develop policy content and choice. Also, the processes of developing policy options tend to be more institutionalized and formalized, all of which tend to make 'core' foreign policy more 'pluralist', as its negotiation and development has to take into account many inputs, some of which, depending on the ideas of the decision-maker (agent), will obstruct or promote desired foreign policy direction. ${ }^{8}$ If agents are seeking to change the status quo which implies challenging prevailing structural conditions, due to the high political salience of so many factors acting as potential foreign policy determinants and constraining decisionmaking, such agents may find little room for independent manoeuvre.

\footnotetext{
${ }^{8}$ For 'elitist' and 'pluralist' foreign policy-making see Robinsion (2012: 169).
} 
The processes of making 'peripheral' foreign policy are generally less structurally bounded, and more agency-prone. Here, structural conditions, while still overall important in underpinning the range of options agents can adopt, have lower salience and rigidity than those found within 'core' foreign policy, and there is greater scope for agency in manoeuvring foreign policy preferences and choice. This is not to suggest that decision-makers (agents) can do whatever they want, but that the political salience of some determinants of foreign policy-making is weak or non-existent, leaving more opportunities for 'elitist' policy-making. Here foreign policy-making is done at the 'elite' level (political leaders and top-level bureaucrats), with fewer other policy inputs to account for. If agents are seeking to change the status quo, due to the lack of politically highly salient factors excessively constraining decision-making, they may find more room for independent manoeuvre. ${ }^{9}$

\section{The goals of 'Core' and 'Peripheral' foreign policy}

The goals of 'core' and 'peripheral' foreign policy can be qualitatively very different, and are helpfully distinguished by a hierarchy of foreign policy interests. Every nation has a hierarchy of 'greater and lesser interests', with certain interests being defended and

\footnotetext{
${ }^{9}$ This generalization about structure and agency in policy-making processes in 'core' and 'peripheral' foreign policy is primarily applicable to pluralist multiparty political systems, and may not be as applicable in authoritarian and dictatorial systems, at least as far as the domestic determinants of foreign policy (such as interest groups, the media, 'issue salience' and public opinion) are concerned. However, notwithstanding the accentuated role individual authoritarian leaders and dictators play in making foreign policy, regardless of the nature of the political system such leaders would still (to varying degrees) have to negotiate pluralist and elitist policy-making environments (Oppermann 2014: 28).
} 
pursued 'at all costs'; others safeguarded and pursued 'under particular circumstances'; and yet others, although desirable, unlikely to be vigorously pursued (Macridis and Thompson 1967: 2-3). The first set of interests fall within 'core' foreign policy, while the last set of interests fall within 'peripheral' foreign policy. 'Core' foreign policy goals, as informed by this hierarchy of interests, are likely to be pursued and defended vigorously at all times, while 'peripheral' foreign policy goals are most likely to be sacrificed or compromised. The former do, and the latter, although desirable, do not significantly impact the state's ideological, strategic, and economic well-being. The middle set of interests can be located at various points along the typology spectrum. These interests inform the types of foreign policy goals that are most likely to allow issues and regions to migrate from one type of foreign policy to another.

Given the limited amount of resources governments can devote to pursuing foreign policy goals, and the priorities set on pursing such goals, one helpful way of thinking about 'core' foreign policy goals may be as 'possession goals'. There are conceptual and qualitative differences between goals pertaining to 'national possessions' and those pertaining to 'the shape of the environment in which the nation operates'; the former being 'possession goals', and the latter 'milieu goals' (Wolfers 1962: 73). In attaining 'possession goals' states aim at 'the enhancement or the preservation' of one or more of the things to which they attach primal value (Ibid.: 73, 74). Because they are aimed at maintaining or enhancing fundamental aspects of a state's ideological, strategic, 
and economic immediate well-being, 'core' foreign policy goals can often be portrayed as concrete; for example, negotiating a specific security alliance and/or trade deal. However, this should not suggest that the goals of 'core' foreign policy are always guided by rational and pragmatic calculations. They are guided by the decision-makers' conceptualization and understanding of how best to preserve and/or enhance key ideological, strategic, and economic values, and as such can also seem rather irrational and cost ineffective at times. Seemingly irrational and ineffective policies can be pursued for rational factors, such as contributing to the popularity of the government and therefore a high possibility of re-election, and policies that are unpopular with the electorate may still be pursued because they appease a particularly powerful domestic constituency (which holds significant sway over the decision-making process), or a powerful foreign interest group.

'Peripheral' foreign policy goals can be conceived as predominantly 'milieu goals'. States pursuing 'milieu goals' 'are not out to defend or increase possessions they hold to the exclusion of others, but aim instead at shaping conditions' beyond their national borders and in the wider international socio-political and economic environment (Wolfers 1962: 74). Of course, the achievement of 'core' foreign policy goals can also shape the wider international environment, and 'milieu goals' can also be pursued in 'core' foreign policy. The distinction is not empirically exact, but for analytical purposes it can be argued that 'milieu goals' are more characteristic of 'peripheral' foreign policy. 
The nature and urgency of the pursuit of 'milieu' goals can help improve or tarnish a state's international reputation and stature. All states, regardless of their size and resources, are rationally expected to overwhelmingly focus their attention on pursuing 'possession' goals. However, the level of activity and input into pursuing 'milieu' goals allows states to actively participate in a geographic region or policy space which is so far removed from their 'core' foreign policy, that their active participation in itself signifies their credentials as great, regional, or middle powers, and 'good international citizens' seemingly interested in more than just their own (narrowly defined) immediate wellbeing. This cuts both ways, and a very low regard for engaging with 'milieu' goals can also harm those states' international reputation and standing, particularly if they are perceived by other states as having the influence and resources necessary to pursue such 'milieu' goals, but actively choose not to.

\section{Goals in between the two types of foreign policy}

In a state's hierarchy of foreign policy interests, there is a 'middle' set of interests (to be safeguarded and pursued under particular circumstances) which can be located at various points alongside the 'core/peripheral' foreign policy spectrum. Such interests inform the types of goals that have the potential to allow issues and regions to migrate from 'peripheral' to 'core' foreign policy. Some milieu goals can often be 'a means or a way station' toward possession goals (Wolfers 1962: 74). For example, a state may pursue certain milieu goals within 'peripheral' foreign policy, which are indeed a 'way station' 
towards achieving certain possession goals, or may become in themselves possession goals. If they are a) only a 'way station' towards possession goals, their realization will not influence a change from 'peripheral' to 'core' foreign policy; if they become b) possession goals, they will influence that change.

An example of a) can be a state's pursuit of a non-permanent membership of the United Nations Security Council. Membership of the Security Council can be considered a 'core' foreign policy goal for most states because it is possessive in nature and pursued at the exclusion of others, allowing states direct influence over the highest organ of security governance of the current international system. But in order to secure votes for such membership, a state may need to more closely engage with issues and areas usually sitting at the margins of its foreign policy agenda. This closer engagement with 'peripheral' foreign policy could be seen as a 'way station' for achieving a concrete possession goal (securing Security Council membership). On the other hand, an example of b) could be a state's persistent pursuit of a rather aspirational milieu goal of, for example, 'good governance' in 'peripheral' foreign policy, which ends up benefitting that country’s ‘core’ foreign policy interests, and becoming a possession goal in itself. Hence, if Canada is funding 'good governance' projects like new taxation regimes or anticorruption legislation in Kenya, governance improvements from such projects could aid Canadian companies in doing business and increasing their profits, thereby beneficially influencing Canada’s overall economic well-being. If, due to such changes in Kenya's 
business appeal, Canadian companies were to significantly increase their commercial links with Kenya, a substantial economic connection between the two states could develop, which could push (economic) engagement between them towards Canada's 'core' foreign policy, possibly resulting in specific possession goals (free trade agreements).

\section{Summarising the key qualitative differences between the two types of foreign policy}

The key qualitative differences between the two ideal types of foreign policy are summarized as follows (Table 1.):

- 'Core' foreign policy is aimed at regions and issues perceived as being of significant ideological, strategic, and economic importance for a country’s immediate well-being; its policy-making processes are more structurally bounded and pluralist; and its goals are more possessive in nature (and often perceived as concrete)

- 'Peripheral' foreign policy is aimed at regions and issues perceived as being of marginal ideological, strategic, and economic importance for a country’s immediate well-being; its policy-making processes are more agency prone and elitist; and its goals are less possessive and more value based, normative, and aspirational (in terms of goal expectations). 
A key distinction between the two types of foreign policy concerns the nature of policy-making with regards to affecting change in foreign policy direction. The significant institutionalization of foreign policy-making processes, the interdependence of foreign policy relationships, and the crowdedness of politically highly salient interests trying to influence its processes and goals, all make 'core' foreign policy much less prone to rapid foreign policy change and volatility, as compared to 'peripheral' foreign policy. This is not to say that 'core' foreign policy is static and without change, but that barring rapidly developing and unexpected events (man or nature made), change is usually incremental and slowly evolving. In 'peripheral' foreign policy change can be more rapid and frequent, and this can primarily be ascribed to the elitist nature of policy-making processes, which are less robustly constrained by their institutionalization, interdependence of foreign policy relationships, and crowdedness of politically highly salient interests trying to influence its processes and goals. 
Table 1. Summary of qualitative differences between the ideal types of foreign policy

\begin{tabular}{|c|c|}
\hline \multirow{2}{*}{ 'Core' } & 'Peripheral' \\
\hline $\begin{array}{c}\text { Issues and regions considered of } \\
\text { significant ideological, strategic, and } \\
\text { economic importance for a state's } \\
\text { immediate well-being }\end{array}$ & $\begin{array}{c}\text { Issues and regions considered of marginal } \\
\text { ideological, strategic, and economic } \\
\text { importance for a state's immediate well- } \\
\text { being }\end{array}$ \\
\hline $\begin{array}{c}\text { Policy-making more structurally } \\
\text { bounded, and pluralist }\end{array}$ & $\begin{array}{c}\text { Policy-making more agency prone, and } \\
\text { elitist }\end{array}$ \\
\hline \begin{tabular}{c} 
'Possession' goals: more concrete \\
\hline
\end{tabular} & 'Milieu' goals: more aspirational \\
\hline
\end{tabular}

\section{Change in foreign policy types}

Having outlined the two ideal types of foreign policy, it is also important to briefly discuss how issues and regions from one type can change into the other. The area between the two types is where many foreign policy issues and regions sit, and is arguably the most interesting area for further study, developing theoretical propositions about how, why, and under which circumstances foreign policy types change. ${ }^{10}$ Such changes can occur relatively rapidly, in a matter of years, or over a more prolonged period of time.

One example of a 'peripheral' foreign policy issue migrating towards 'core' foreign policy is the 'Global War on Terror'. Prior to the 11 September 2001 terrorist

\footnotetext{
10 Theory building generally begins with definitions and establishing analytical boundaries. The next step, which I plan on developing in a book-length study, is to examine issues and areas of foreign policy that sit between these ideal types, outlining a theoretical framework for change in foreign policy types. I am grateful to one of the reviewers for underlining the importance of this point.
} 
attacks on the United States, many Western states did not devote much interest and resources to the fight against (Islamic) terrorism, save for perhaps what was deemed necessary for narrowly interpreted domestic security purposes. Australia, for example, 'did not rank international terrorism high among the probable threats' to its interests, and 'responding to terrorism was not an Australian government priority' in the 1990s (Ungerer 2008: 4-5). However, since then, Australia has gone to war in Afghanistan and Iraq, devoting a significant amount of foreign and defence policy attention and resources to the 'Global War on Terror', as well as domestic and counter-terrorism activities. Whilst before 2001 the fight against international terrorism was firmly in Australia’s 'peripheral' foreign policy, by the mid-2000s it became as fundamental feature of the country's 'core' foreign policy.

There are also examples of the reverse; issues and regions from 'core' foreign policy migrating to 'peripheral' foreign policy. This happens when engagement with certain states and issues receives a decreasing amount of priority and attention, which can be caused by a mix of ideological, strategic, and economic reasons. To use the example of Australia again, close ideological, strategic, and economic ties with the United Kingdom are no longer within Australia's 'core' foreign policy in the way they were in the first two thirds of the 1900s, mostly due to the end of Britain's empire and changing global strategic and economic circumstances, as well as Australia's closer cultural, 
strategic, and economic association with the United States since the end of the Cold-War (Broinowski and Curran 2014).

\section{Conclusion}

IR theory is 'too general to stand as the theory of foreign policy' (Smith 1987: 346), while FPA is for the most part too detailed and specific to do the same. My hope is that this typology of foreign policy can contribute towards FPA's development of a theory of foreign policy. In the European 'analysis of foreign policy' tradition, this typology's contribution is towards 'middle-range' theory building, supporting FPA's ability to answer broader questions about why foreign policy priorities differ, and how such differences impact on the very nature of foreign policy-making. In this vain, I have tried to explain how states order the world by theorizing 'core' and 'peripheral' foreign policy, and establishing generalizable markers about the nature of foreign policy-making within these two types.

I invoked the issue of structure and agency to argue that 'core' foreign policymaking is more structurally bounded and may be less prone to rapid change, while 'peripheral' foreign policy is more agency prone and can change more rapidly. This helps add analytical clarity to understanding different foreign policy priorities and behaviour. In contrast with previous efforts at explaining more and less important areas of foreign policy, my typology offers clearly demarcated and generalizable categories for 
understanding how states prioritize their foreign policy. The typology outlines how different factors help determine foreign policy, and how the political salience of such determinants varies in the two types. It also explains why the different types embody different foreign policy-making dynamics and goals, and how the pursuit of some goals can help issues and regions migrate from one foreign policy type to another.

Theorizing about the nature of foreign policy as a policy-making activity, is an important step in supporting FPA's ‘middle-range’ theory development, as it can provide generalizable hypotheses about differing foreign policy priorities and behaviour which can be tested through case-studies. Although much of FPA's empirical literature appears focused on distinct and idiosyncratic cases that provide historical explanations of foreign policy behaviour, 'middle-range' theorizing should aid us in narrowing the scope of explanations and predictions of future foreign policy behaviour. My hope is that this typology of foreign policy can aid us in better understanding and predicting foreign policy decisions and direction.

\section{References}

ALONS, GERRY C. (2007) Predicting a State’s Foreign Policy: State Preferences between Domestic and International Constraints. Foreign Policy Analysis 3: 211-232. 
BROINOWSKI, ALISON and JAMES CURRAN. (2014) The US Alliance. In Australian Foreign Policy. Controversies and Debates. Edited by Daniel Baldino, Andrew Carr, and Anthony J. Langlois. Melbourne: Oxford University Press, 118-134.

BUZAN, BARRY. (1991) People, states and fear: an agenda for international security studies in the post-cold war era. $2^{\text {nd }}$ ed. New York; London: Harvester Wheatsheaf.

CARLSNAES, WALTER. (1992) The Agency-Structure Problem in Foreign Policy Analysis. International Studies Quarterly 36: 245-270.

CARLSNAES, WALTER. (2012) Actors, structures, and foreign policy analysis. In Foreign Policy. Theories, Actors, Cases, $2^{\text {nd }}$ ed., edited by Steve Smith, Amelia Hadfield, and Tim Dunne. Oxford: Oxford University Press, 113-129.

DEUTSCH, KARL W., SYDNEY A. BURRELL, ROBERT A. KANN, MAURICE LEE, JR., MARTIN LICHTERMAN, RAYMOND E. LINDGREN, FRANCIS L. LOEWENHEIM, and RICHARD W. VAN WAGENEN. (1968) Political community and the North Atlantic area: international organization in the light of historical experience. Publication of the Center for Research on World Political Institutions, Princeton University. Princeton, N. J.: Princeton University Press.

FRIEDMAN, GIL and HARVEY STARR. (1997) Agency, Structure, and International Politics. From ontology to empirical inquiry. London: Routledge. 
HAY, COLIN. (1995) Structure and Agency. In Theory and Methods in Political Science, edited by David Marsh and Gerry Stoker. Basingstoke: Palgrave, 189-206.

HAY, COLIN. (2002) Political Analysis: a critical introduction. Basingstoke: Palgrave Macmillan.

HUDSON, VALERIE M. (2005) Foreign Policy Analysis: Actor-Specific Theory and the Ground of International Relations. Foreign Policy Analysis 1: 1-30.

HUDSON, VALERIE M. (2007) Foreign policy analysis: classic and contemporary theory. Lanham: Rowman \& Littlefield Pub.

HUDSON, VALERIE M. (2012) The History and Evolution of Foreign Policy Analysis. In Foreign Policy. Theories, Actors, Cases, $2^{\text {nd }}$ ed., edited by Steve Smith, Amelia Hadfield, and Tim Dunne. Oxford: Oxford University Press, 13-34.

LANDSBERG, CHRIS. (2014) The Concentric Circles of South Africa’s Foreign Policy under Jacob Zuma. India Quarterly: A Journal of International Affairs 70: 153-172.

MACRIDIS, ROY C. and KENNETH W. THOMPSON. (1967) The Comparative Study of Foreign Policy. In Foreign policy in world politics, edited by Roy C. Macridis. Englewood Cliffs, N.J.: Prentice-Hall, 1-28. 
MINTZ, ALEX and NEHEMIA GEVA. (1997) The Poliheuristic Theory of Foreign Policy Decisionmaking. In Decision-Making on War and Peace. The CognitiveRational Debate, edited by Nehemia Geva, and Alex Mintz. Boulder: Lynne Rienner. OPPERMANN, KAI and ALEXANDER SPENCER. (2013) Thinking Alike? Salience and Metaphor Analysis as Cognitive Approaches to Foreign Policy Analysis. Foreign Policy Analysis 9: 39-56.

OPPERMANN, KAI. (2014) Delineating the Scope Conditions of the Poliheuristic Theory of Foreign Policy Decision Making: The Noncompensatory Principle and the Domestic Salience of Foreign Policy. Foreign Policy Analysis 10: 23-41.

PUTNAM, ROBERT D. (1988) Diplomacy and Domestic Politics: The Logic of TwoLevel Games. International Organization 42: 427-460.

ROBINSON, PIERS. (2012) The role of media and public opinion. In Foreign Policy. Theories, Actors, Cases, $2^{\text {nd }}$ ed., edited by Steve Smith, Amelia Hadfield, and Tim Dunne. Oxford: Oxford University Press, 168-187.

ROSE, GIDEON. (1998) Neoclassical Realism and Theories of Foreign Policy. World Politics 51: 144-172.

SMITH, STEVE (1987) Foreign Policy Analysis and International Relations. Millennium - Journal of International Studies 16: 345-348. 
UNGERER, CARL. (2008) Introduction: Australian foreign policy after 9/11. In Australian foreign policy in the age of terror. Edited by Carl Ungerer. Sydney, N.S.W.: UNSW Press, 1-22.

WALTZ, KENNETH N. (1979) Theory of International Politics. Reading, MA: AddisonWesley.

WALTZ, KENNETH N. (1996) International Politics is Not Foreign Policy. Security Studies 6 (1): 54-57.

WIGHT, COLIN. (2006) Agents, Structures and International Relations. Cambridge: Cambridge University Press.

WOHLFORTH, WILLIAM C. (2012) Realism and foreign policy. In Foreign Policy. Theories, Actors, Cases. $2^{\text {nd }}$ ed., edited by Steve Smith, Amanda Hatfield, and Tim Dunne. Oxford: Oxford University Press, 35-54.

WOLFERS, ARNOLD. (1962) Discord and collaboration: essays on international politics. Baltimore: Johns Hopkins Press. 